\title{
NO EVIDENCE OF VERTICAL TRANSMISSION OF HTLV-I IN BOTTLE-FED CHILDREN
}

\author{
Achiléa L BitTenCourT(1), Ester C. SABINO(2), Maria Cecília COSTA(3), Celia PEDroso(4) \& Licia MOREIRA(5)
}

\begin{abstract}
SUMMARY
The most frequent pathway of vertical transmission of HTLV-I is breast-feeding, however bottle fed children may also become infected in a frequency varying from 4 to $14 \%$. In these children the most probable routes of infection are transplacental or contamination in the birth canal.

Forty-one bottle-fed children of HTLV-I seropositive mothers in ages varying from three to 39 months (average age of 11 months) were submitted to nested polymerase chain reaction analysis ( $\mathrm{pol}$ and tax genes). $81.5 \%$ of the children were born by an elective cesarean section.
\end{abstract}

No case of infection was detected. The absence of HTLV-I infection in these cases indicates that transmission by transplacental route may be very infrequent.

KEYWORDS: HTLV-I infection; HTLV-I vertical transmission; Transmission through breast-feeding; Diagnosis by PCR.

\section{INTRODUCTION}

The most frequent pathway of vertical transmission of HTLV-I is breast-feeding. Through prenatal screening for HTLV-I and the refraining from breast-feeding for the carrier mothers a reduction of $\sim 80 \%$ of vertical transmission has been observed in $\mathrm{Japan}^{5}$. Serologic surveys of breast-fed children of carrier mothers using different methods of detection reported infection rates varying from $10 \%$ to $28 \%$ and indicate that the rate of transmission is directly related to the time of breast-feeding ${ }^{5-}$ $7,15,18,20$. However bottle-fed children may also become infected vertically in a frequency varying from $4 \%$ to $14 \% \%^{5-7,15,18,20}$.

Besides breast-feeding the other possible mechanisms of vertical transmission of infections are: transplacental or hematogenous, by ascending microrganisms from the vagina (ascending via), by fetus contamination in the birth canal during delivery or by intimate contact between mother and child. The mechanism of vertical transmission of HTLV-I in bottle-fed infants remains to be established, however the most probable routes of infection may be transplacental or contamination in birth canal. Many researchers have shown that elective cesarian delivery reduces mother-to-child transmission in other blood born viral infections mainly because direct contact with blood is avoided $d^{4,8,11-13,19}$. On the other hand, in labor uterine contractions can disrupt the placental barrier resulting in transplacental microtransfusions from mother to fetus. It has been shown that maternal microtransfusion to the fetus can be affected by different modes of delivery, but elective cesarean presents the least microtransfusion risk ${ }^{11}$.

Considering these facts, we decided to evaluate the vertical transmission of HTLV-I in breast-fed children born through elective cesarean section.

\section{MATERIAL AND METHODS}

The mothers were screened serologically for HTLV-I through ELISA and Western blot. The methods of screening were detailed in another paper $^{2}$. The mothers were informed about the research and those who consented were submitted to cesarean section and were advised to refrain from breast-feeding. Pediatric assistance and an alternative nutritional supply were provided for the babies. Testing for HTLV-I DNA was performed by nested polymerase chain reaction (PCR) on peripheral blood mononuclear cells of forty-one bottle-fed children. Permission was obtained from all the mothers of the children included in this study.

PCR testing: Mononuclear cells were isolated from peripheral blood of children by density centrifugation through Ficoll-Conray gradient. The peripheral blood mononuclear cells pellet was washed twice with $0.9 \% \mathrm{NaCl}$ and re-suspended in $100 \mu \mathrm{l}$ of lysis buffer $(10 \mathrm{mM}$ Trisbuffer [pH 8.3], 0.5\% Nonidet P-40, 0.5\% Tween 20) and digested with $40 \mu \mathrm{g}$ of proteinase $\mathrm{K}$ at $65^{\circ} \mathrm{C}$ for 2 hours. All samples were subjected to

(1) Associate Professor of Pathology, Federal University of Bahia (UFBA); Researcher of National Research Council - CNPq, Brazil.

(2) Head, Department of Molecular Biology, Fundação Pró-Sangue/Hemocentro, Universidade de São Paulo (USP), São Paulo, SP, Brazil.

(3) Biologist of Fundação Pró-Sangue, USP, São Paulo, SP, Brazil.

(4) Biologist of the Laboratory of Retrovirology of Hospital Prof. Edgard Santos, UFBA, Salvador, BA, Brazil.

(5) PhD in Pediatrics; Professor of Neonatology, UFBA, Salvador, BA Brazil.

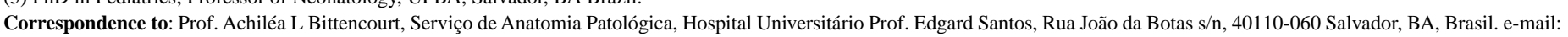
achilea@uol.com.br 
PCR amplification for HTLV tax gene. Due to technical problems, we could only perform PCR for the pol gene on 28 of the 41 samples. For the pol gene, $1 \mu \mathrm{g}$ of DNA was amplified in one round with primers SK110 (4384-4405 5'CCCTACAATCAACCAGCTCAG) and SK111 (4569-4547 5'GTGGTGAAGCTGCCATCGGGTTTT) in a reaction mixture containing $3.0 \mathrm{mM} \mathrm{MgCl} 2$ and $0.2 \mathrm{mM}$ each primer. The PCR product was detected by liquid hybridization with a radio labeled probe SK112 (4452-4573 5’GTACTTTACTGACAAACCCGACCTAC) for HTLV-I. To detect the tax gene, DNA was amplified by a nested PCR with SK43 (6985-7003 5'CGGATACCCAGTCTACGT) and SK44 (7143-7123 5'GAGCCGATAACGCGTCCATCG) in the first round and TAX1 (7001-7020 5'-GTGTTTGGCGATTGTGTACA-3') and TAX2 (7128-7112 5'-CCATCGATGGGGTCCCA-3') in the second round in a reaction mixture containing $2.5 \mathrm{mM} \mathrm{MgCl} 2$ and $0.2 \mathrm{mM}$ each primer. The PCR product was analyzed upon electrophoresis on a $1 \%$ agarose gel $^{16}$. A T-cell line (MT-2) infected with HTLV-1 was used as positive control. PBMC from seronegative individuals were used as negative controls. Positive and negative controls were included in every run. All samples were also submitted to PCR for the beta globin gene to detect the presence of PCR inhibitors.

\section{RESULTS}

From $52 \mathrm{HTLV}$-I+ mothers included in a previous study ${ }^{2}$ only fortyone non breast-fed children could be contacted for PCR studies in ages varying from three months to 39 months (average age of 11 months). $81.5 \%$ of the mothers have had an elective cesarean section. Sixty per cent of these mothers were previously submitted to PCR studies with positive results ${ }^{2}$. Four children were born prematurely and one, born at term, was small for gestational age. Twenty-one were male and 20 were female. None of the children received blood transfusions. PCR amplification for the tax gene was done in all the cases and for the pol gene in 28 cases, and the results were negative for both amplifications.

\section{DISCUSSION}

In South America there has been no evaluation of vertical transmission of the HTLV-I until now. It is known that in Salvador, Bahia, $0.84 \%$ of pregnant women of low socioeconomic class are HTLV-I carriers $^{2}$. Furthermore, the occurrence of many cases of adult T-cell leukemia/lymphoma ${ }^{1}$ and infective dermatitis in Salvador, Bahia ${ }^{3}$, diseases associated with the vertical transmission of HTLV-I ${ }^{10,17}$, indicates the importance of this route of infection in this city.

In this study the children were tested by nested PCR because this method is more sensitive for the detection of HTLV-I infection than conventional serology and is very useful for diagnosis of this infection early in life, before seroconversion, that occurs between one and three years of age $e^{5,9}$. In the laboratory of Molecular Biology, Fundação PróSangue/Hemocentro, USP, Brazil the sensitivity of PCR was $90 \%$ when seropositive blood donors were used as positive controls ${ }^{16}$. Using conventional serology MONPLAISIR et al. (1993) ${ }^{14}$ found $7 \%$ of infection among 27 children (ages varying from 2 to 12 years) born to HTLV-I seropositive mothers, but when they used PCR the frequency of transmission increased to $41 \%$.

As previously stated, bottle-fed children can be infected vertically in a frequency varying from $4 \%$ to $14 \%$. However, in the present study no case of vertical transmission was observed in 41 bottle-fed children. The absence of infection determined by a sensitive method indicates that transmission by the transplacental route may be very infrequent. It is possible that the artificial delivery that occurred in $81.5 \%$ of the cases may have contributed to the absence of transmission.

\section{RESUMO}

\section{Ausência de transmissão vertical do HTLV-I em crianças não amamentadas}

A amamentação é o meio mais freqüente de transmissão vertical do HTLV-I. No entanto, crianças não amamentadas mostram-se infectadas em frequiências que variam de 4 a 14\%. Nestes casos, os meios mais prováveis de infecção devem ser através da placenta ou por contaminação no canal de parto. Quarenta e um filhos de portadoras do HTLV-I aleitados artificialmente foram submetidos a pesquisa do vírus pela reação em cadeia da polimerase. $81,5 \%$ destas crianças nasceram através de cesária eletiva. Nenhum caso de infecção pelo HTLV-I foi detectado. Este fato indica que a infecção por via transplacentária é pouco freqüente e que é provável que o parto artificial tenha contribuído para a ausência de transmissão do vírus.

\section{ACKNOWLEDGMENTS}

The authors are grateful to Dr Aldely Rocha Dias for providing the nutritional support for the babies and for Drs James Cadidé and Magnolia Santos for the obstetrical assistance. This work was supported by Superintendência de Apoio ao Desenvolvimento Científico e Tecnológico (CADCT), and CNPq.

\section{REFERENCES}

1. BARBOSA, H.S.; BITTENCOURT, A.L.; BARRETO DE ARAUJO, I. et al. - Adult Tcell leukemia/lymphoma in northeastern Brazil: a clinical, histopathologic, and molecular study. J. Acquir. Immune Defic. Syndr., 21: 65-71, 1999.

2. BITTENCOURT, A.L.; DOURADO, I.; BASTOS FILHO, P. et al. - Human T-cell lymphotropic virus type 1 infection among pregnant women in northeastern Brazil. J. Acquir. Immune Defic. Syndr., 26: 490-494, 2001.

3. BITTENCOURT, A.L. \& OLIVEIRA, M.F. - Dermatite infecciosa associada ao HTLVI. Revisão. An. bras. Derm., 76: 723-732, 2001.

4. DULIEGE, A.M.; AMOS, C.I.; FELTON, S.; BIGGAR, R.J. \& GOEDERT, J.J. - Birth order, delivery route, and concordance in the transmission of human immunodeficiency virus type 1 from mothers to twins. International Registry of HIV-Exposed Twins. J. Pediat., 126: 625-632, 1995.

5. HINO, S.; KATAMINE, S.; MIYATA, H. et al. - Primary prevention of HTLV-I in Japan. Leukemia, 11: 57-59, 1997.

6. HIRATA, M.; HAYASHI, J.; NOGUCHI, A. et al. - The effects of breast-feeding and presence of antibody to $\mathrm{p} 40 \mathrm{tax}$ protein of human $\mathrm{T}$ cell lymphotropic virus type-I on mother-to-child transmission. Int. J. Epidem., 21: 989-994, 1992.

7. IKEDA, K.; INABA, N. \& TAKAMIZAWA, H. - Vertical transmission human T-cell lymphotropic virus type-I (HTLV-I): genetic diagnosis and assessment of the probable routes of HTLV-I infection. Nippon Sanka Fujinka Gakkai Zasshi, 45: 1283-1288, 1993.

8. KIND, C.; RUDIN, C.; SIEGRIST, C.A. et al. - Prevention of vertical HIV transmission: additive protective effect of elective cesarean section and zidovudine prophylaxis. Swiss Neonatal HIV Study Group. AIDS, 12: 205-210, 1998. 
9. KUSUHARA, K.; SONODA, S.; TAKAHASHI, K. et al. - Mother-to-child transmission of T-cell leukemia virus type I (HTLV-I): a fifteen-year follow-up study in Okinawa, Japan. Int. J. Cancer, 40: 755-757, 1987.

10. LA GRENADE, L. - HTLV-I-associated infective dermatitis: past, present, and future. J. Acquir. Immune Defic. Syndr., 13(suppl. 1): S42-S49, 1996.

11. LIN, H.; KAO, J.; HSU, H. et al. - Least microtransfusion from mother to fetus in elective cesarean delivery. Obstet. and Gynec., 87: 244-248, 1996

12. MAGUIRE, A.; SÁNCHEZ, E.; FORTUNY, C. \& CASABONA, J. - Potential risk factors for vertical HIV-1 transmission in Catalonia, Spain: the protective role of cesarean section. The Working Group on HIV-1 Vertical Transmission in Catalonia. AIDS, 11: $1851-1857,1997$.

13. MANDELBROT, L.; CHENADEC, J.; BERREB, A. et al. - Perinatal HIV-1 transmission: interaction between zidovudine prophylaxis and mode of delivery in the French Perinatal Cohort. J. Amer. med. Ass., 280: 55-60, 1998

14. MONPLAISIR; N.; NEISSON-VERNANT, C.; BOUILLOT, M. et al. - HTLV-I maternal transmission in Martinique, using serology and polymerase chain reaction. AIDS Res. hum. Retrovir., 9: 869-874, 1993.

15. OKI, T.; YOSHINAGA, M.; OTSUKA, M. et al. - A sero-epidemiological study on motherto-child transmission of HTLV-I in Southern Kyushu, Japan. Asia Oceania J. Obstet. Gynaec., 18: 371-377, 1992.
16. SABINO, E.C.;ZREIN, M.; TABORDA, C.P. et al. - Evaluation of the INNO-LIA HTLV$\mathrm{I} / \mathrm{II}$ assay for confirmation of human T-cell leukemia virus-reactive sera in blood bank donations. J. clin. Microbiol., 57: 1324-1328, 1999.

17. SUGIYAMA, H.; DOI, H.; YAMAGUCHI, K. et al. - Significance of postnatal motherto-child transmission of human T-lymphotropic virus type-I on the development of adult T-cell leukemia/lymphoma. J. med. Virol., 20: 253-260, 1986.

18. TAKAHASHI, K.; TAKESAKI, T.; OKI, T. et al. - Inhibitory effect of maternal antibody on mother to child transmission of human T-lymphotropic virus type I. The Motherto-Child Transmission Study Group. Int. J. Cancer, 49: 673-677, 1991.

19. THE EUROPEAN COLLABORATIVE STUDY - Cesarean section and risk of vertical transmission of HIV-1 infection. Lancet, 343: 1464-1467, 1994.

20. URETA-VIDAL, A.; ANGELIN-DUCLOS, C.; TORTEVOYE, P. et al. - Mother-to-child transmission of human T-cell-leukemia/lymphoma virus type I: implication of high antiviral antibody titer and high proviral load in carrier mothers. Int. J. Cancer, 82 832-836, 1999.

Received: 28 October 2001

Accepted: 11 April 2002 